(2) Open Access Full Text Article

\title{
Intraosseous epidermoid cyst of the finger phalanx: a case report
}

This article was published in the following Dove Press journal:

Orthopedic Research and Reviews

18 Septembers 2010

Number of times this article has been viewed

\author{
Nipun Kalsotra \\ Manjeet Singh \\ Siddhartha Sharma \\ Dara Singh \\ Department of Orthopaedics, \\ Government Medical College Jammu, \\ Jammu and Kashmir State, India
}

\begin{abstract}
Epidermoid cysts of the finger phalanx are rare pseudotumors. They are benign lesions with a satisfactory outcome after excision. It is important to differentiate this benign lesion, which can be easily treated by curettage, from other benign and malignant lesions of the bone with a similar clinical presentation, and which may require amputation. We describe a case of an epidermoid cyst in the distal phalanx of the ring finger. It was treated successfully and the patient had excellent functional results at one-year follow-up.
\end{abstract}

Keywords: finger phalanx, epidermoid cyst, lytic bone lesion

\section{Introduction}

Intraosseous epidermoid cyst are squamous epithelial lined benign cysts within the bone, presenting clinically as radiolucent lytic bone lesions. Clinically, distinguishing them from neoplastic and inflammatory bone lesions can be challenging, and requires pathological evaluation for definitive diagnosis. Since a definitive diagnosis can only be made by histological evaluation, intraosseous epidermoid cyst tend to be misdiagnosed and underreported. It is regarded as a traumatic or an iatrogenic lesion and can be clinically and radiologically deceptive. ${ }^{1}$ This paper presents a rare intraosseous tumour of the distal phalanx of the ring finger.

\section{Case presentation}

A 24-year-old Indian male farmer presented with a one-month history of painful swelling in the distal phalanx of his right ring finger. The patient had sustained an injury to his finger six months before after which the finger enlarged gradually and painlessly for the first few months. The past medical history was insignificant; there was no history of fever, night pain, or radiation exposure. The family, occupational, recreational, and drug histories were insignificant. The general physical and systemic examinations were within normal limits.

Clinical examination revealed a swollen distal phalanx of the right ring finger with bulging of the nail bed (Figure 1). Sensation and circulation were normal. Regional lymph nodes were not enlarged. Radiography showed a radiolucent lesion involving the distal phalanx that caused bone expansion and cortical thinning (Figure 2).

Needle biopsy of the lesion was performed and it showed polygonal squamous cells with keratinizing cellular debris, consistent with the diagnosis of an intraosseous epidermoid cyst. Initial differential diagnoses included osteomyelitis, enchondroma, gout, and aneursymal bone cyst. 
a

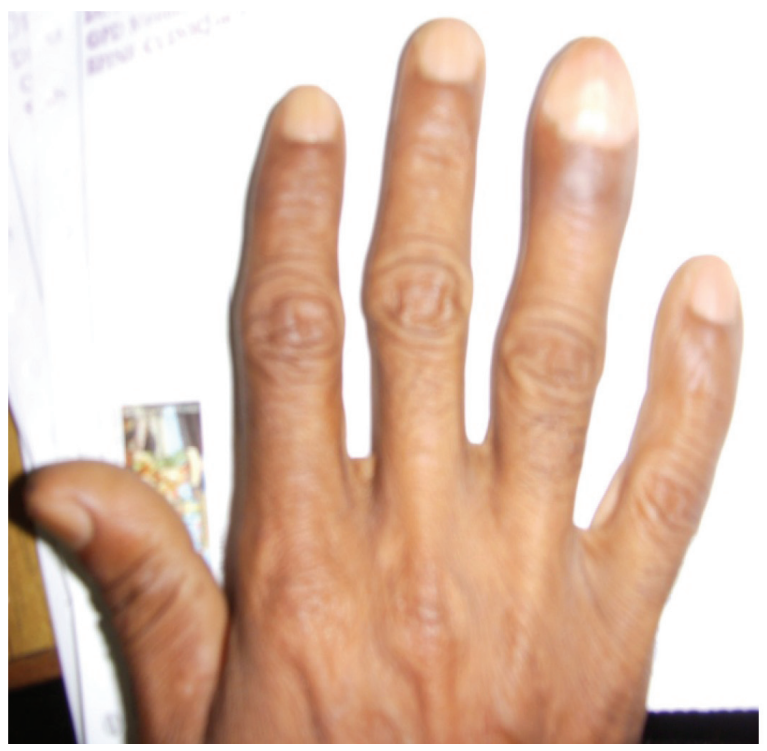

Figure I a, b) Intraosseous epidermoid cyst of distal phalanx of right ring finger.

Intraoperatively, the bone cortex was as thin as an eggshell; when the lesion was incised, yellow-tan cheese like creamy material was released, and a thick layer of tissue was peeled from within the cavity of the lesion. Curettage of the lesion was performed. Histopatholgical examination revealed that the wall of the cyst was composed of squamous cells, and the cavity was full of keratinized lamellar material. Postoperative recovery was uneventful. Remoulding of the distal phalanx was progressive and at one-year follow-up, the patient had a normal looking finger and nail.

a

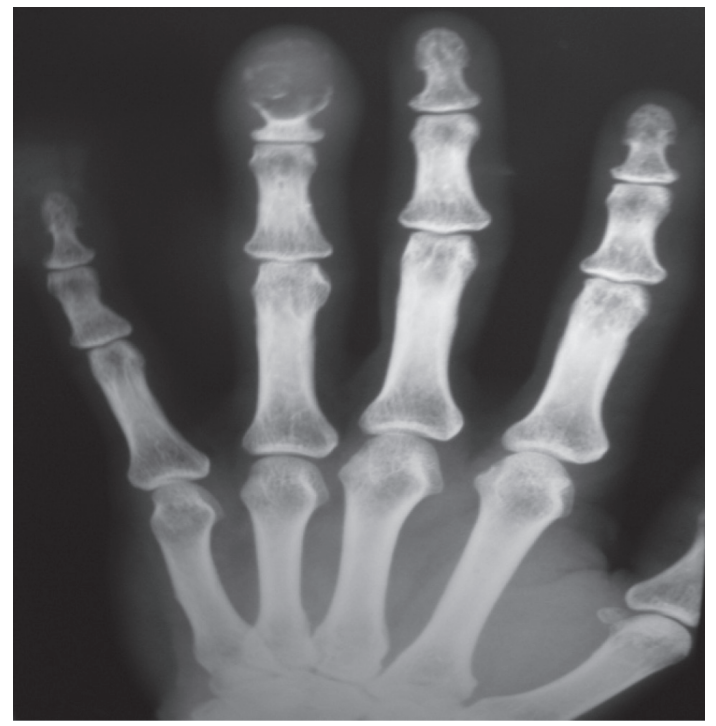

Figure 2a X-ray (AP view) showing intraosseous epidermoid cyst of distal phalanx of right ring finger. b

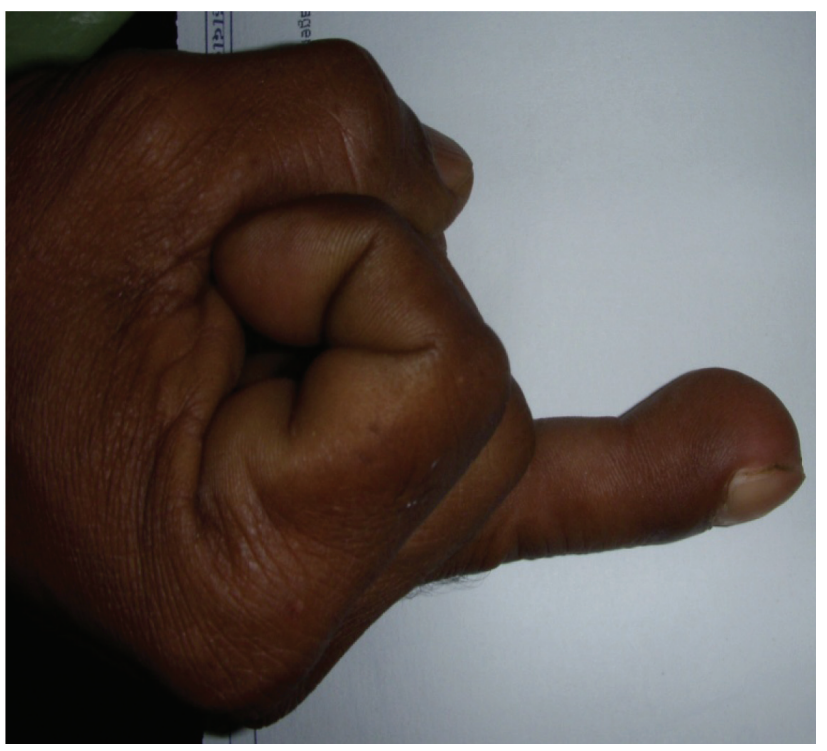

\section{Discussion}

Epidermoid bone cysts are rare and usually involve the skull and the phalanges. Harris initially documented intraosseous epidermoid cysts of the digits in $1930 .{ }^{9}$ The lesion is most common in adults, especially manual workers; males are more frequently affected than females. Patients are most often in their fourth or fifth decade of life (range 8 to 83 years). The most common site for phalangeal involvement is the distal phalanx of the fingers. ${ }^{2,3}$ They are regarded as congenital, traumatic, or iatrogenic in origin. ${ }^{1}$ The time from implantation to presentation of the cyst is not known as the

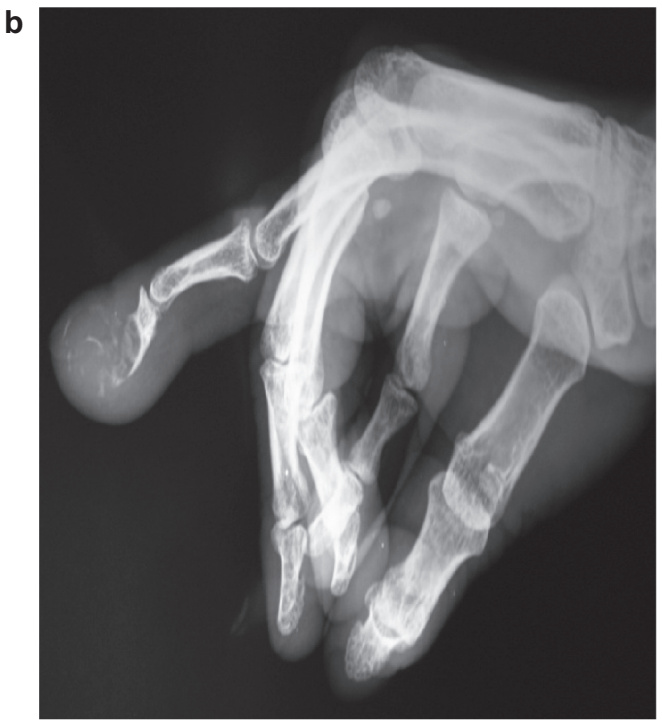

Figure 2b X-ray (lateral view) showing intraosseous epidermoid cyst of distal phalanx of right ring finger. 
precipitating trauma is often minor. The pathogenesis of phalangeal intraosseous epidermoid cyst is not known. It has been proposed that it may result from implantation of epithelial cells into the subcutaneous tissues as a result of trauma. ${ }^{3,4}$ Surviving cells would subsequently proliferate and produce keratin. ${ }^{6}$ It is thought that phalangeal intraosseous epidermoid cyst, occurring in the absence of trauma, may be due to the proliferation of intraosseous inclusions of epithelial elements during embryogenesis. ${ }^{6}$ Clinically the lesions typically occur in the distal phalanx and present with variable degrees of pain, swelling, nail deformity, and sometimes erythema. The pain may be sudden onset if there is a pathological fracture, or more gradual. It is exacerbated by minor trauma and by pressure on the nail bed, and it is throbbing in nature. There may be a pathological fracture of the phalanx. The skin is often normal in appearance, though there may be scars from previous trauma. The nail is usually deformed with pseudoclubbing and loss of its normal smooth surface. The radiographic features are typically those of an expansile radiolucency, which may be elliptical in the longitudinal axis of the phalanx, without trabeculations. The cortex is usually thinned and may perforate the volar or dorsal aspect but there is no periosteal reaction unless the cyst becomes infected or there are attempts of healing of microfractures.

The lesion has sclerotic margins and adjacent soft tissue swelling. Histologically, intraosseous epidermoid cysts have a stratified squamous epithelial capsule surrounding centrally deposited keratin. Diagnosing epidermoid bone cysts can be a clinical and radiological challenge. Differential diagnoses include chronic infection or a chondroma, intraosseous ganglion, bone cyst, giant cell tumor, even a metastatic lesion. ${ }^{3,7}$ The most effective treatment of phalangeal intraosseous epidermoid cyst is surgical excision, with curettage of the phalanx. ${ }^{8}$ Bone grafting may be necessary for large defects. If the cyst is completely removed, the recurrence rate is low. Histopatholgical evaluations are necessary for the correct diagnosis; a needle aspiration may be sufficient for making a correct preoperative diagnosis if enough keratin or sebaceous material is obtained. ${ }^{4}$

\section{Disclosure}

No conflicts of interest were declared in relation to this paper.

\section{References}

1. Schajowicz F, Aiello CL, Slullitel I. Cystic and pseudocystic lesions of the terminal phalanx with special reference to epidermoid cysts. Clin Orthop Relat Res. 1970;68:84-92.

2. Hinrichs RA. Epidermoid cyst of the terminal phalanx of the hand. Case report and brief review. JAMA. 1965;194:1253-1254.

3. Wang BY, Eisler J, Springfield D, Klein MJ. Intraosseous epidermoid inclusion cyst in a great toe. A case report and review of the literature. Arch Pathol Lab Med. 2003;127:e298-e300.

4. Handa U, Kumar S, Mohan H. Aspiration cytology of epidermoid cyst of terminal phalanx. Diagn Cytopathol. 2002;26:266-267.

5. Lucas GL. Epidermoid inclusion cysts of the hand. J South Orthop Assoc. 1999;8:188-192.

6. Niccoli C, Mambelli V. La cisti epiteliale endoossea della falangetta. Arch Putti Chir Organi Mov. 1978;29:395-404.

7. Kozlowski K, Azouz EM, Campbell J, et al. Primary bone tumours of the hand. Report of 21 cases. Pediatr Radiol. 1988;18:140-148.

8. Belusa M. Intra-osseous epidermoid cyst [in German]. Handchir Mikrochir Plast Chir. 1991;23:200-201.

9. Harris RI. Sebaceous cyst of the terminal phalanx of the thumb, an unusual form of bone tumor. J Bone Joint Surg. 1930;12:647-648.
Orthopedic Research and Reviews

\section{Publish your work in this journal}

Orthopedic Research and Reviews is an international, peer-reviewed, open access journal focusing on the patho-physiology of the musculoskeletal system, trauma, surgery and other corrective interventions to restore mobility and function. Advances in new technologies, materials, techniques and pharmacological agents are particularly welcome. The journal welcomes

\section{Dovepress}

original research, clinical studies, reviews \& evaluations, expert opinion and commentary, case reports and extended reports. The manuscript management system is completely online and includes a very quick and fair peer-review system, which is all easy to use. Visit http://www.dovepress. com/testimonials.php to read real quotes from published authors. 